\title{
Glomerular function and hyperuricaemia in sickle cell disease
}

\author{
AG MORGAN, K DE CEULAER, GR SERJEANT
}

From the Department of Medicine and Medical Research Council Laboratories, University of the West Indies, Kingston 7, Jamaica

SUMMARY Renal insufficiency is common in adults with homozygous sickle cell disease, and the contribution of glomerular failure to the hyperuricaemia which is often a feature of the disease has therefore been investigated. In a study of 64 patients between the ages of 15 and 66 , serum urate concentration was dependent on renal urate clearance and also on creatinine clearance. The relation between serum urate and creatinine clearance was abnormal in patients with sickle cell disease and it is suggested that this might be caused by high single nephron glomerular filtration rates. Both the amount of urate excreted per millilitre of glomerular filtrate and the fractional excretion of urate increased with falling creatinine clearance, suggesting that the ability to increase tubular urate secretion was preserved. Patients with extensive tubular disease as shown by tubular proteinuria had serum urate concentrations which were not significantly different from those of age and sex matched non-proteinuric patients. Evidence that renal tubular disease interferes with urate secretion and causes hyperuricaemia in patients with sickle cell disease needs to be reinterpreted in the light of these findings.

Hyperuricaemia, which is common in homozygous sickle cell disease, has been ascribed to diminished urate excretion as a consequence of altered renal tubular function. ${ }^{\prime}$ The possible contribution of altered glomerular function has not been explored, even though diminishing filtration rate is an important feature in older patients. ${ }^{2}$ We have therefore investigated the influence of age, creatinine clearance, and tubular damage, as shown by tubular proteinuria, on serum urate concentration and urinary urate excretion. In a previous study ${ }^{3}$ hyperuricaemia appeared unrelated to bone marrow activity as judged by haemoglobin concentration, reticulocyte count, and serum bilirubin concentration, and these observations have now been extended by measurements of red cell mass and red cell survival.

\section{Patients and methods}

Sixty four patients with homozygous sickle cell disease attending the Sickle Cell Clinic at the University Hospital of the West Indies, Kingston, Jamaica, were admitted to a metabolic ward when free of acute complications of their disease. All patients had given informed consent to inclusion in the study. The diagnosis of sickle cell disease was based on

Accepted for publication 23 May 1984 haemoglobin electrophoresis on cellulose acetate and agar gel, measurement of haemoglobin $\mathrm{A}_{2}$, anc family study where possible. The mean age of the 35 female patients studied $(42.8$ years, range 15 to 66 years) was not significantly different from that of the 29 men (mean $37 \cdot 5$ years, range 18 to 65 years).

At the time of study no patient was taking any drug known to affect urate metabolism, and all ate a normal hospital diet. Urine alkalinisation ( $\mathrm{pH}$ greater than 6.0) was achieved by oral administration of sodium bicarbonate, and aliquots for urate estimation were diluted with an equal volume of $0.2 \mathrm{M}$ borate buffer, $\mathrm{pH} \mathrm{8.0.} \mathrm{Two} \mathrm{consecutive,} \mathrm{supervised}$ $24 \mathrm{~h}$ urine collections were made and accompanying serum samples were taken. Urate and creatinine concentrations were measured as previously described, ${ }^{3}$ and mean values for each patient were calculated; clearance and $24 \mathrm{~h}$ excretion values were corrected for body surface area derived from height and weight. Urate excretion per millilitre of glomerular filtrate was calculated from:

$$
\frac{24 \mathrm{~h} \text { urinary urate }}{\text { creatinine clearance } \times 24 \times 60}
$$

and fractional excretion of urate from: $\underline{\text { urate clearance } \times 100}$ creatinine clearance 
Urinary albumin concentration was measured by single radial immunodiffusion on urine concentrated 10 -fold by ultrafiltration (Amicon membrane UM10) and urinary $\beta_{2}$-microglobulin by radioimmunoassay on unconcentrated urine (Phadebas beta-2-microtest).

Serum urate concentration and $24 \mathrm{~h}$ urinary urate excretion were also measured in 19 women with sickle cell disease (mean age 31.8 years, range 21 to 42 years) during the baseline phase of a separate study. ${ }^{4}$ Red cell mass, red cell survival, and indices of renal urate handling were measured using methods described elsewhere. ${ }^{4}$

Student's $t$ test and linear regression analysis were used for statistical analysis of results, with log transformation of data where appropriate.

\section{Results}

Serum urate concentrations ranged between 0.24 and $0.91 \mathrm{mmol} / \mathrm{l}$ and were significantly higher in male patients (mean \pm SD $0.50 \pm 0.12 \mathrm{mmol} / \mathrm{l}$ ) compared with female patients $(0.42 \pm 0.15 \mathrm{mmol} / \mathrm{l}$, $\mathrm{p}<0.05)$. Twenty four of $29(83 \%)$ male patients and 16 of $35(46 \%)$ female patients had values above $0.39 \mathrm{mmol} / \mathrm{l}$, the concentration at which serum becomes supersaturated with urate. ${ }^{5}$ In neither sex was serum urate significantly correlated with age.

Serum urate concentration was negatively correlated with urate clearance (Fig. 1) $(r=-0 \cdot 76, p<$ $0.001)$ and also with creatinine clearance (Fig. 2) (r $=-0.49, \mathrm{p}<0.001)$, but was not related to total urinary urate excretion $(r=-0 \cdot 22, p>0.05)$. Both urate excretion per millilitre of glomerular filtrate (Fig. 3) $(r=-0.83, p<0.001)$ and fractional excre-

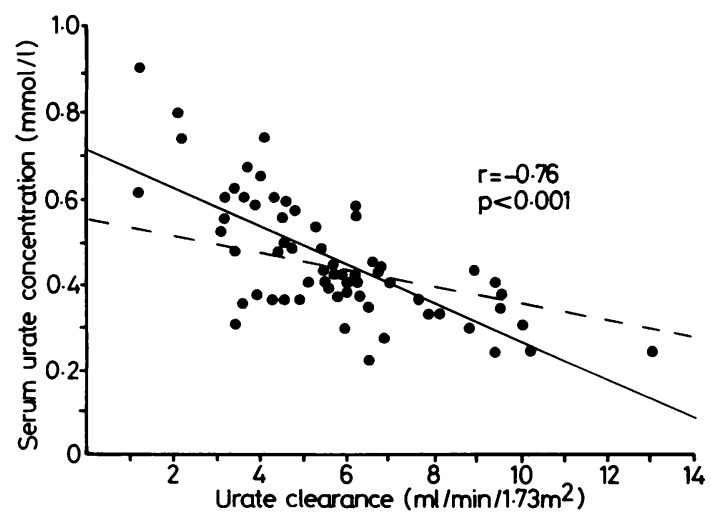

Fig. 1 Relation between serum urate concentration and urate clearance. Broken line shows the relation found by Steele and Rieselbach ${ }^{8}$ in patients without homozygous sickle cell disease $(r=-0 \cdot 63)$.

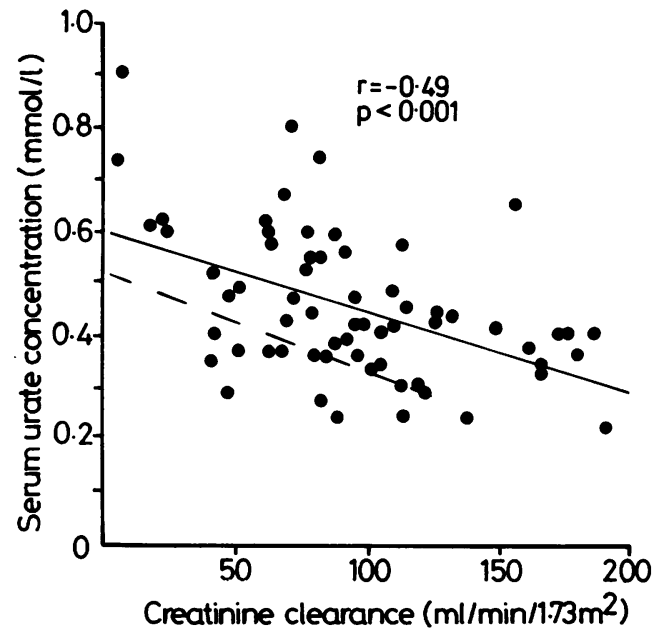

Fig. 2 Relation between serum urate concentration and creatinine clearance. Broken line shows the relation found by Steele and Rieselbach ${ }^{8}{ }^{9}$ in patients without homozygous sickle cell disease $(r=-0.65)$.

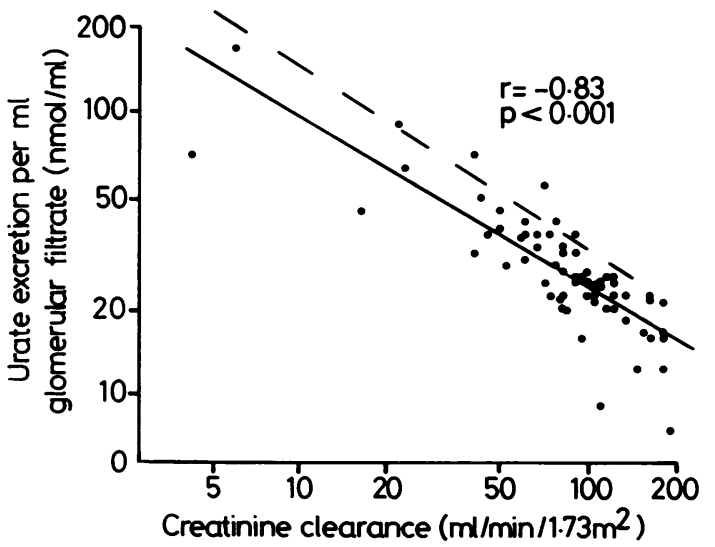

Fig. 3 Relation between log urate excretion per $\mathrm{ml}$ glomerular filtrate and log creatinine clearance. Broken line shows the relation found by Steele and Rieselbach ${ }^{89}$ in patients without homozygous sickle cell disease $(r=$ $-0.93)$.

tion of urate $(r=-0.60, p<0.001)$ were negatively correlated with creatinine clearance. Total urinary urate excretion was positively correlated with creatinine clearance $(\mathrm{r}=0.61, \mathrm{p}<0.001)$.

In 10 of the 18 patients who excreted more than $300 \mathrm{mg}$ urinary protein per day, the ratio of urinary albumin concentration to urinary $\beta_{2}$-microglobulin concentration was less than $0 \cdot 3$, indicating tubular proteinuria, ${ }^{6}$ whereas the remainder had ratios which indicated mixed or glomerular proteinuria. Three of the patients with tubular proteinuria had appreciable glomerular failure (creatinine clearance less than $24 \mathrm{ml} / \mathrm{min} / 1 \cdot 73 \mathrm{~m}^{2}$ ) and were therefore 
excluded from further comparisons. The remaining seven patients with tubular proteinuria but relatively normal glomerular function were then compared with a control group of patients with sickle cell disease without proteinuria by matching each with the two patients in the remainder of the study group who were of the same sex and closest in age (Table). Although mean serum urate concentration was higher in the patients with tubular proteinuria than in the controls, this difference was not significant. There were no significant differences in age, creatinine clearance, or indices of urate excretion.

Patients with tubular proteinuria compared with age and sex matched non-proteinuric patients

\begin{tabular}{|c|c|c|}
\hline & $\begin{array}{l}\text { Tubular } \\
\text { proteinuria }\end{array}$ & No proteinuria \\
\hline Number & 7 & 14 \\
\hline Sex (male: female) & & $12: 2$ \\
\hline Age (yr) & $40 \pm 16$ & $39 \pm 14$ \\
\hline Serum urate $(\mathrm{mmol} / \mathrm{l})$ & $0.52 \pm 0.09$ & $0.43 \pm 0.11$ \\
\hline Urinary urate excretion & & \\
\hline $\begin{array}{l}\left(\mathrm{mmol} / \mathrm{d} / 1.73 \mathrm{~m}^{2}\right) \\
\text { Urate clearance }\left(\mathrm{ml} / \mathrm{min} / 1.73 \mathrm{~m}^{2}\right)\end{array}$ & $3 \cdot 40 \pm 0 \cdot 5$ & $3.58 \pm 0.62$ \\
\hline $\begin{array}{l}\text { Urate clearance }\left(\mathrm{ml} / \mathrm{min} / 1.73 \mathrm{~m}^{2}\right) \\
\text { Creatinine clearance }\end{array}$ & $4 \cdot 8 \pm 1 \cdot 1$ & $1 \cdot 9$ \\
\hline$\left(\mathrm{ml} / \mathrm{min} / 1.73 \mathrm{~m}^{2}\right)$ & $115 \pm 46$ & $99 \pm 34$ \\
\hline Urate excretion per $\mathrm{ml}$ glomerula & & \\
\hline $\begin{array}{l}\text { filtrate }(\mathrm{nmol} / \mathrm{ml}) \\
\text { Fractional excretion of urate }(\%)\end{array}$ & $\begin{array}{l}24 \cdot 5 \pm 10 \cdot 7 \\
4 \cdot 8 \pm 2 \cdot 2\end{array}$ & $\begin{array}{l}27 \cdot 2 \pm 8 \cdot 1 \\
6 \cdot 5 \pm 1 \cdot 9\end{array}$ \\
\hline
\end{tabular}

Values given as mean \pm standard deviation.

In the 19 patients in whom red cell mass and red cell survival was measured, serum urate concentration ranged from 0.18 to $0.48 \mathrm{mmol} / \mathrm{l}$ (mean 0.27 $\mathrm{mmol} / \mathrm{l})$. Red cell mass ranged from 13.7 to $20 \cdot 1$ $\mathrm{ml} / \mathrm{kg}$ (mean $17.2 \mathrm{ml} / \mathrm{kg}$ ) and red cell survival (half life) ranged from 4.5 to 21.2 days (mean 10.9 days). There were no significant correlations between serum urate concentration and red cell mass, red cell survival, ratio of red cell mass to red cell survival, haemoglobin concentration, or reticulocyte count, but serum urate was negatively correlated with urate clearance $(r=-0.63, p<0.01)$.

\section{Discussion}

The main factors which influence serum urate concentration are the metabolic production of urate and the way in which it is excreted by the kidneys. Earlier studies ${ }^{13}$ have shown that renal urate clearance is a major determinant of serum urate in homozygous sickle cell disease, and our present study confirms this. On the other hand, serum urate concentration has no relation to urate production judged by daily urinary urate excretion, nor to haemoglobin or reticulocyte count, suggesting that hyperuricaemia in sickle cell disease is not closely related to increased bone marrow activity. This con- clusion receives further support from the measurements of red cell mass and survival, which showed no correlation between red cell turnover and serum urate concentration. Nevertheless, we cannot altogether exclude an effect of increased purine turnover since we have only studied a selected group of young female patients, most of whom were not hyperuricaemic.

Our finding that serum urate concentration was correlated with creatinine clearance suggests that glomerular function has an important effect on urate excretion. We have therefore compared our results with those of Steele and Rieselbach, ${ }^{89}$ who studied serum urate concentration and glomerular function in normal subjects and in patients with renal insufficiency. The relation between serum urate and urate clearance in sickle cell patients is similar to that found in normal subjects (Fig. 1), but the regression line of serum urate on creatinine clearance (Fig. 2) is displaced to the right of that for non-sickle cell disease patients. A comparison of this sort needs to be interpreted with caution since the difference observed could arise if our method for urate estimation gave higher values than that of Steele and Rieselbach, ${ }^{89}$ or if our measurements of creatinine clearance overestimated inulin clearance. A systematic difference of urate concentrations is unlikely, however, because urate excretion per millilitre of glomerular filtrate (Fig. 3) and fractional excretion of urate both appeared lower in patients with sicklece cell disease than in normal subjects. These indices? are also of interest because they show that urate excretion per nephron increases with falling glomerular filtration rate as it does in normal subjects, a phenomenon usually attributed to enhanced tubular urate secretion. ${ }^{9}$ Our relatively high values of creatinine clearance in some patients with sickle cell disease are consistent with other reports $^{10} 11$ indicating that supranormal glomerular filtration rates, measured by either inulin or creatinine clearance, are common. It therefore appears that urate excretion in patients with sickle cell disease is inappropriately low in relation to glomerular filtration rate even though the ability to increase excretion with falling creatinine clearance is preserved.

A possible explanation for our findings stems from the observations that glomeruli in sickle cell disease are particularly large ${ }^{12}$ and that glomerular filtration rates in children and young adults are well above normal. ${ }^{1011}$ The number of glomeruli in children with sickle cell disease is normal, ${ }^{12}$ so single nephron glomerular filtration rate must be high. Despite the greater filtered load, tubular secretion of urate per nephron would not have to be any greater than normal, whatever proportion of urate was reab- 
sorbed proximally, in order to prevent hyperuricaemia. The relation between serum urate and urate clearance (Fig. 1) would be preserved, but urate excretion per millilitre of glomerular filtrate (Fig. 4) would appear low because creatinine clearance gives a falsely great impression of the number of functioning nephrons. If normal tubular adaptive processes occurred with the loss of nephrons which is a notable feature of ageing in sickle cell disease patients (Morgan and Shah, unpublished observations) the excretion of urate would increase with falling creatinine clearance (Fig. 3).

There is clear clinical and pathological evidence of renal tubular damage in sickle cell disease,${ }^{13}$ but it is not possible to draw firm conclusions concerning the role of such damage in the genesis of hyperuricaemia. Sickle cell disease patients with tubular proteinuria, who might be expected to have extensive damage that included the proximal tubules, where urate reabsorption and secretion occur, did not have significantly higher serum urate concentrations than others. The evidence suggesting that enhanced tubular urate secretion occurs in patients with low glomerular filtration rates also argues against this transport mechanism being limited by structural damage. We can only draw conclusions by inference, however, since we have not performed specific tests of tubular urate handling. Diamond $e t$ $a^{1}$ carried out such tests, but there are insufficient data to allow us to determine whether tubular urate secretion varied with glomerular filtration rate, as we would predict. It is interesting to note, however, that their results show a negative correlation between serum urate and creatinine clearance $(r=$ $-0.71, p<0.01$ ). Further studies of uric acid secretion in sickle cell disease are needed and account should be taken of the likelihood that single nephrom glomerular filtration rates are high and of the frequency of renal insufficiency in older patients.
This work was supported in part by the Wellcome Trust.

\section{References}

' Diamond HS, Meisel AD, Holden D. The natural history of urate overproduction in sickle cell anaemia. Ann Intern Med 1979;90:752-7.

${ }^{2}$ Morgan AG, Serjeant GR. Renal function in patients over 40 with homozygous sickle-cell disease. $\mathrm{Br}$ Med $\mathrm{J}$ 1981;282:1181-3.

${ }^{3}$ De Ceulaer K, Morgan AG, Choo-Kang E, Wilson WA, Serjeant GR. Serum urate concentrations in homozygous sickle cell disease. J Clin Pathol 1981;34:965-9.

${ }^{4}$ De Ceulaer K, Gruber C, Hayes R, Serjeant GR. Medroxyprogesterone acetate and homozygous sickle cell disease. Lancet 1982;ii: 229-31.

${ }^{5}$ Holmes EW. Pathogenesis of hyperuricaemia in primary gout. Clin Rheum Dis 1977;3:3-23.

- Peterson PA, Evrin P-E, Berggard I. Differentiation of glomerular, tubular, and normal proteinuria: determinations of urinary excretion of beta-2-microglobulin, albumin and total protein. $J$ Clin Invest 1969;48:1189-98.

${ }^{7}$ Lubega J. Beta-2-microglobulin and the analytical characterisation of proteinuria. Med Lab Sci 1982;39:129-38.

" Steele TH, Rieselbach RE. The renal mechanism for urate homeostasis in normal man. Am J Med 1967;43:868-75.

' Steele TH, Rieselbach RE. The contribution of residual nephrons within the chronically diseased kidney to urate homeostasis in man. Am J Med 1967;43:876-86.

${ }^{10}$ Etteldorf JN, Tuttle AH, Clayton GW. Renal function studies in paediatrics. 1. Renal haemodynamics in children with sickle cell anaemia. Am J Dis Child 1952;83:185-91.

" Hatch FE, Azar SH, Ainsworth TE, Nardo JM, Culbertson JW. Renal circulatory studies in young adults with sickle cell anaemia. J Lab Clin Med 1970;76:632-40.

${ }^{12}$ Bernstein J, Whitten C. A histological appraisal of the kidney in sickle cell anaemia. Arch Pathol 1960;70:407-18.

${ }^{13}$ Alleyne GAO, Statius Van Eps LW, Addae SK, Nicholson GD, Schouten $\mathrm{H}$. The kidney in sickle cell anaemia. Kidney Int 1975; 7:371-9.

Requests for reprints to: Dr AG Morgan, Nottingham Renal Unit, City Hospital, Nottingham NG5 1PB. 